\title{
Wastelands: their attractiveness and importance for preserving the diversity of wild bees in urban areas
}

\author{
Lucyna Twerd ${ }^{1}$ [D $\cdot$ Weronika Banaszak-Cibicka ${ }^{2}$
}

Received: 7 June 2018 / Accepted: 25 March 2019 / Published online: 30 March 2019

(c) The Author(s) 2019

\begin{abstract}
Urban wastelands are important substitute habitats for many insect species, but their value for the protection of wild bees is still poorly studied. We assessed species richness, abundance, and the diversity of wild bees in wastelands that differed in area (2-35 ha), stage of ecological succession, location (suburbs or closer to the city centre), and history of land use. In the investigated plots, we recorded $42 \%$ of all bee species reported from Poland. The attractiveness of wastelands was positively correlated with the coverage of blooming herbs, coverage of shrubs and low trees, and the area of the wasteland. An increase in isolation of the habitat patches, the percentage contribution of alien species, annuals, and low grasses $(<25 \mathrm{~cm})$ negatively affected the diversity of Apiformes. Considering the history of land use, we found that the bees were most attracted to wastelands resulting from extractive industry (sand and clay pits), and grassy habitats located in the suburbs, e.g. at sites grazed earlier by sheep. Wastelands in areas directly influenced by the chemical industry were the least attractive to bees. Analyses of quantitative and qualitative similarity of bees in various habitat types showed that three habitat types were the most similar to grasslands in the suburbs (the least disturbed habitats): degraded grasslands located closer to the city centre, extraction pits, and old fields. The presented results indicate that urban wastelands, including some post-industrial sites, can be important secondary habitats for wild bees. Thus, proper management of urban natural resources should cover both the formally managed areas and the so-called unproductive spaces, which have been undervalued so far.
\end{abstract}

Keywords Apiformes $\cdot$ Biodiversity $\cdot$ Urban wastelands $\cdot$ Ecosystem services

\section{Introduction}

The growth of urban areas is observed worldwide, and the expanding cities cause significant changes in the environment (Aronson et al. 2014; Shochat et al. 2010; McDonnell and Hahs 2008; McKinney 2002). Although urbanization threatens many animal species (McKinney 2006, 2008; Fortel et al. 2014; Concepción et al. 2015; Hamblin et al. 2018), numerous studies show that urban areas also play

Electronic supplementary material The online version of this article (https://doi.org/10.1007/s10841-019-00148-8) contains supplementary material, which is available to authorized users.

Lucyna Twerd

1.twerd@ukw.edu.pl

1 Department of Ecology, Institute of Environmental Biology, Kazimierz Wielki University, Ossolińskich 12, 85-093 Bydgoszcz, Poland

2 Institute of Zoology, Poznań University of Life Sciences, Wojska Polskiego 71C, 60-625 Poznań, Poland a positive role in preserving biodiversity and often function as secondary habitats for some species (Lundholm and Richardson 2010; Menke et al. 2011; Holzer 2014; Eckert et al. 2017; Hall et al. 2017; Banaszak-Cibicka et al. 2018). Urbanization transforms a homogeneous landscape into a mosaic of pavements, buildings, and urban green areas: not only managed (e.g. parks, gardens), but also various types of wastelands. Although the word wasteland has many meanings, usually they are perceived as apparently empty, neglected (Gandy 2013) abandoned sites with spontaneous vegetation. They are found in areas affected by industrial activity (Gallagher et al. 2011; Kattwinkel et al. 2011), after demolition of industrial buildings and warehouses, and near abandoned infrastructure (Albrecht et al. 2007; Fischer et al. 2013a, b; Gardiner et al. 2013). Moreover, in the course of urban development, farmland is commonly transformed into built-up areas, which become significant (in terms of area) components of urban open space.

Wastelands covered with plant species growing without human control are often overlooked in protection schemes. 
However, despite the fact that the image of these areas is often negative, they may be important due to their high floristic diversity (Maurer et al. 2000; Zerbe et al. 2003). Lack of management of urban wastelands encourages varied plant populations to be maintained (Öckinger et al. 2009). Apart from native species, urban wastelands often harbour exotic plants (Godefroid et al. 2007; Muratet et al. 2007). Wastelands are also very dynamic in space and time. They appear and disappear as a result of demolition or construction of residential buildings and changes in infrastructure and green areas. Wastelands of different ages include different stages of vegetation, ranging from pioneer to pre-forest stages, and consequently harbour different communities of plants and animals. Other important factors are the distance between different wasteland areas and their isolation. Higher isolation and distance between convenient habitats act as a factor limiting the occurrence of some species, especially small bees whose foraging range is approx. $150-600 \mathrm{~m}$ from the nesting site (Gathmann and Tscharntke 2002). Connectivity between wastelands influences the biodiversity of wastelands, although to a lesser extent than the local features (Bonthoux et al. 2014).

The variable character of towns and cities (e.g. in respect of their size, age, population density, and rate of urbanization) results in various forms and locations of wastelands in urban areas (Rupprecht and Byrne 2014). For instance, recently created towns are characterized by a larger contribution of open, unmanaged habitats (Hahs et al. 2009), as compared with older administrative units. Simultaneously, differences in the shape and size of wastelands may influence the role played by them in the landscape. Nevertheless, irrespective of their size, they "fill" and supplement the environmental space of towns and cities, simultaneously ensuring the continuity of resources, which is regarded by many authors as a significant factor affecting biodiversity (Niemelä 1999; Savard et al. 2000).

Wild bees, as the most common pollinators, provide crucial ecosystem services in both natural and anthropogenically modified habitats. In urban areas, protective measures are undertaken more and more often to improve their living conditions (construction and installation of bee houses) and to increase the amount and availability of food resources (propagation of bee forage plants, green roofs) (Colla et al. 2009; Tonietto et al. 2011). However, to a large extent, protective measures are undertaken in formally managed green areas, i.e. in urban parks, public and private gardens, and socalled "ecological areas", which are partly protected. That is why we know a lot about the role of managed urban green areas (Matteson et al. 2008; Lermann and Milam 2016; Lermann et al. 2018; Normandin et al. 2017) and urban forest ecosystems (Carper et al. 2014; Banaszak-Cibicka et al. 2018) in shaping the diversity of bees. In contrast, the significance of unmanaged areas, so-called "unproductive spaces") is not only poorly studied but until recently also marginalized in respect of their environmental value.

Urban habitats can be considered as attractive to bees when they provide habitat features necessary for their survival, including the abundance and diversity of flowering plants as forage and a variety of suitable nesting sites. The attractiveness of habitat types can be assessed on the basis of the observed number of bee species.

Spontaneously developing wastelands offer a number of features which are beneficial to bees and do not occur in developed areas. One such feature is permeable soil devoid of vegetation, which provides convenient nesting sites for many species. Another crucial aspect is the presence of native psammophilous or ruderal plant species which do not require care (such as watering) and are an important source of food, especially in the summer. Hence, due to the different habitat conditions, wastelands complement and support natural bee resources found in urban ecosystems. Moreover, at the city scale, they usually constitute a significant part which should be taken into account in urban planning.

Our study was aimed to assess the environmental value of urban wastelands for the survival and protection of wild bees. Hence we determined: (1) which types of wasteland support a high diversity of Apiformes; (2) which features of wastelands are crucial for their attractiveness to bees; (3) which bee species are indicators of the studied habitat types; and (4) how the wastelands should be managed, particularly in the context of biodiversity preservation and development in urban habitats.

\section{Materials and methods}

\section{Study area and study sites}

Field research was conducted in 2016 and 2017 in 14 wastelands located in the city of Bydgoszcz in northern Poland $\left(53^{\circ} 7^{\prime} 24.6^{\prime \prime} \mathrm{N}, 18^{\circ} 0^{\prime} 27.43^{\prime \prime} \mathrm{E}\right)$. Although Bydgoszcz is one of the largest cities in Poland (population about 360,000, area $176 \mathrm{~km}^{2}$ ), it has remarkable environmental values thanks to its location on the river Brda, at its confluence with the Vistula, and the high forest coverage of the adjacent areas. The city is characterized by highly variable land relief, with flat areas of the Vistula valley and its broad glacial valley as well as steep edges of the valley and undulated tops of moraines. As a result of the shape of the terrain, the city is located at an altitude of 28-96 m.

For this study, seven types of wastelands were selected: [A] degraded grasslands in the suburbs; [B] degraded grasslands closer to the city centre; $[\mathrm{C}]$ clay and sand quarries; [D] old fields; [E] sites where industrial buildings or warehouses had been demolished; [F] wastelands in a former military training area; and $[\mathrm{G}]$ wastelands directly affected 
by chemical industry (Figs. 1, 2, 3). We analysed each type of wastelands in two sites.

The wastelands examined were open spaces with high exposure to sunlight. The sites $[\mathrm{A}-\mathrm{C}]$ located in the suburbs, bordering with multi-family residential buildings (about 50-100 from blocks of flats), are often used for sports and recreation. The remaining wastelands were

Fig. 1 Study area

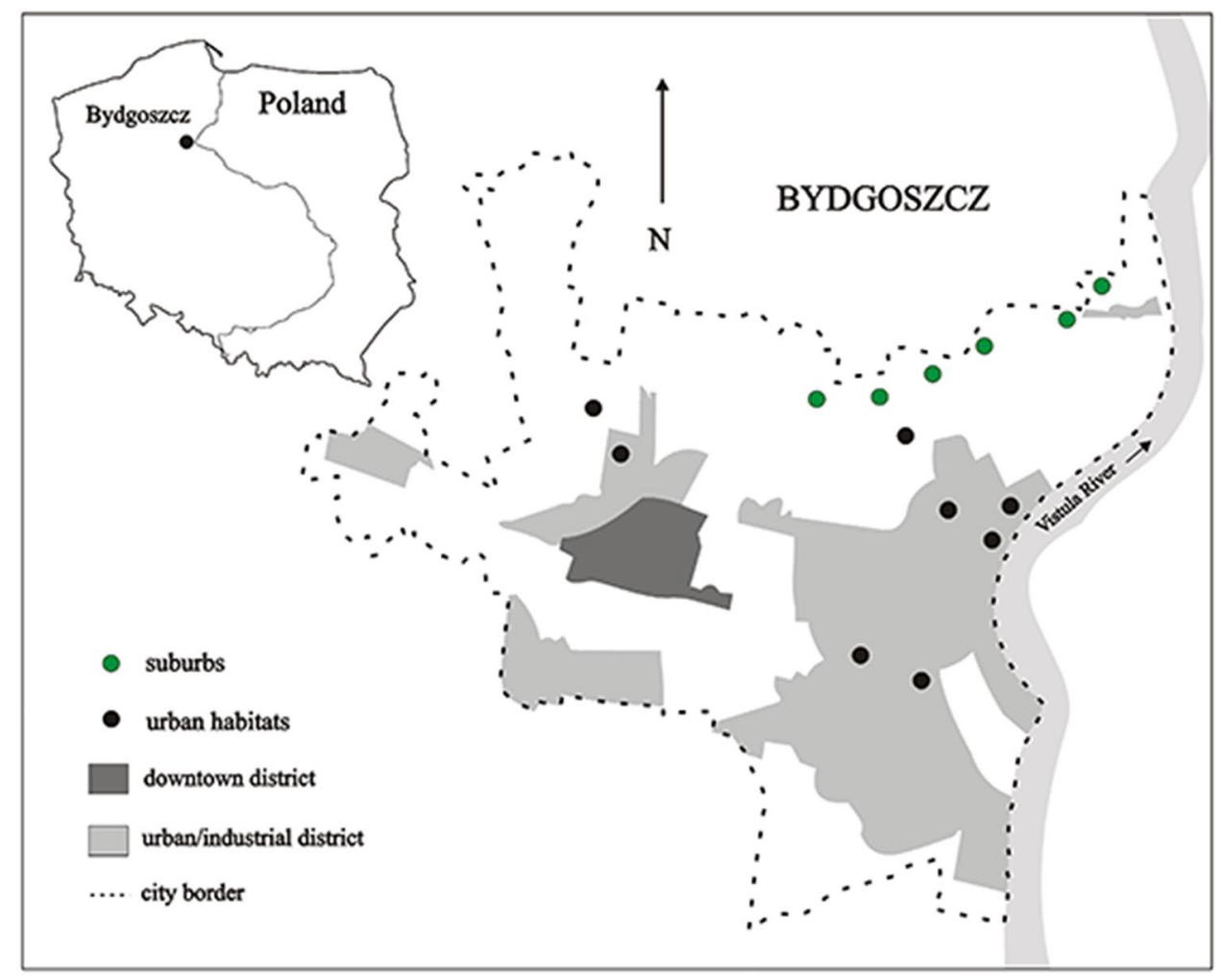

Fig. 2 Wastelands located in the edge zone of the Lower Vistula Valley, on the suburbs of Bydgoszcz

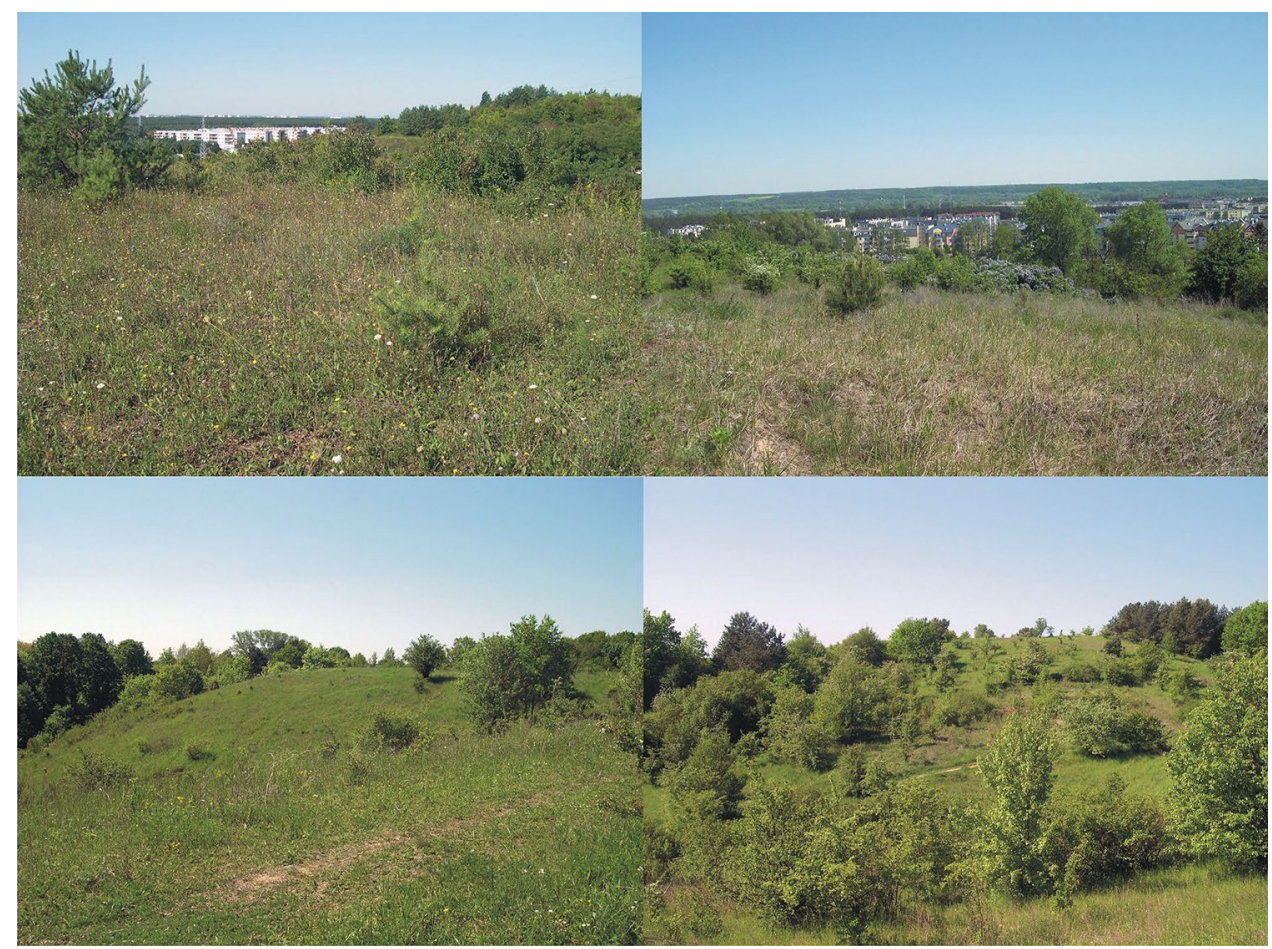


Fig. 3 Wastelands located in the residential/industrial districts of Bydgoszcz

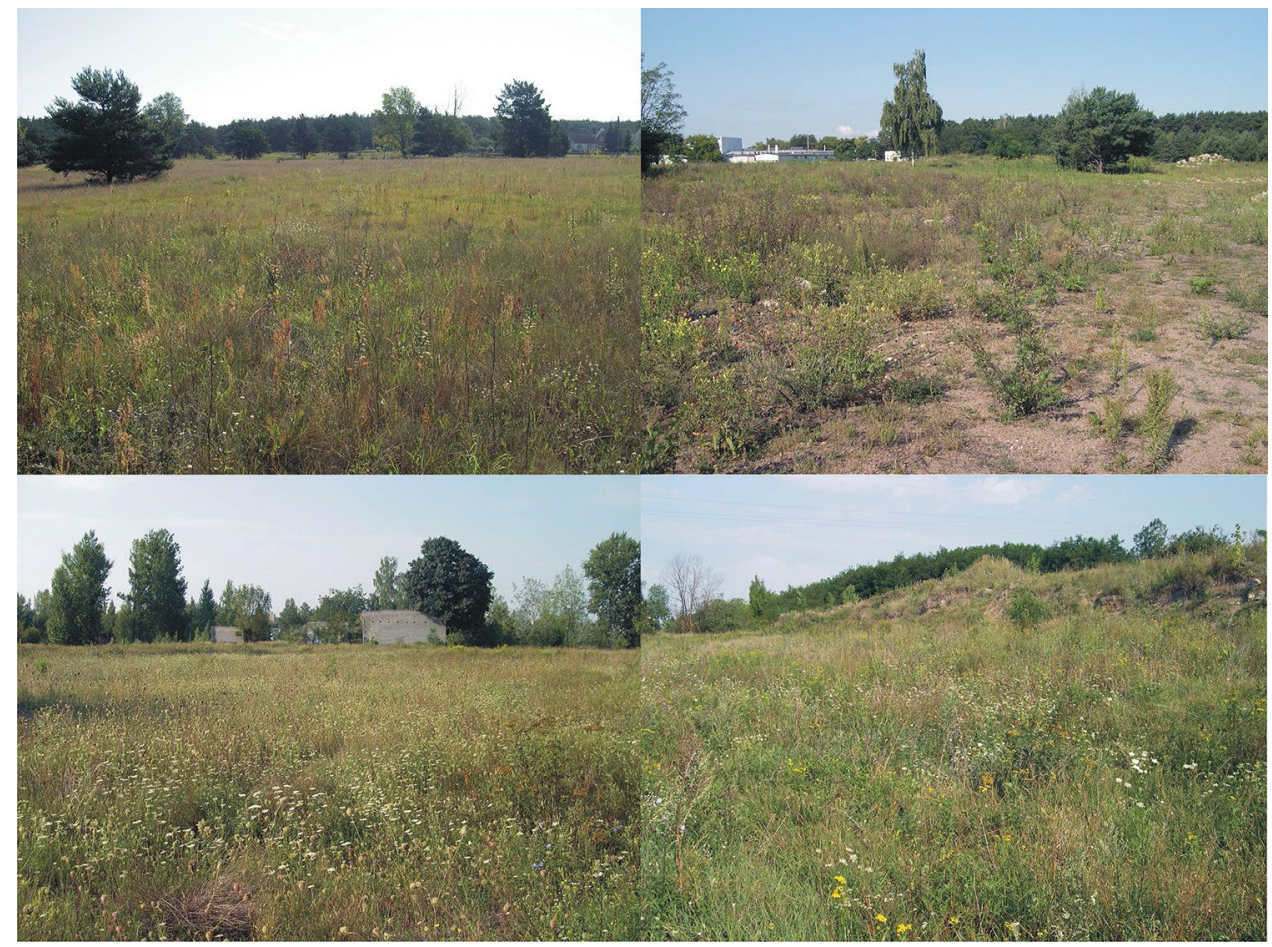

located in isolated places or areas rarely penetrated by humans (Figs. 1, 2, 3).

All the investigated wastelands differed in stages of ecological succession and were covered mostly with synanthropic herbaceous vegetation. The dominant grass species in those habitats were Poa pratensis L., Calamagrostis epigejos (L.) Roth, and Elymus repens (L.) Gould, while the dominant woody species was Pinus sylvestris L. All the plant species recorded at the wastelands are listed in Online Table A1. The plant species nomenclature was adopted after Flora Europaea (Rutkowski 2004).

\section{History of land use in the wastelands}

Sites [A, B] sheep grazing, [C] sand and clay extraction, [D] potato and cereals plantations $[\mathrm{E}]$ areas where warehouses and industrial buildings had been demolished, $[\mathrm{F}]$ a former Prussian military training area (artillery training ground in the late nineteenth century and early twentieth century), [G] area directly affected by a former chemical factory.

\section{Bee sampling}

Insects were caught in 2016 (sites C; D; G) and in 2017 (sites A; B; E; F) from May to August (once a month). Research was conducted after obtaining oral consent from owners and managers of the land and in accordance with applicable law. At each site, bees were collected using the transect method (transects $200 \mathrm{~m}$ long and $1 \mathrm{~m}$ wide) (Banaszak 1980). Bee collection along each transect lasted about $30 \mathrm{~min}$ by two researchers. The number of transects depended on site area: 2 transects $(0.5 \mathrm{~h})$ for $\leq 5 \mathrm{ha}, 4$ transects $(1 \mathrm{~h})$ for $6-10 \mathrm{ha}, 6$ transects $(1.5 \mathrm{~h})$ for $11-15 \mathrm{ha}$, and 8 transects $(2 \mathrm{~h})$ for $>15 \mathrm{ha}$. In total, 4900 samples were taken $(70$ transects $\times 5$ months $\times 14$ sites). The insects were collected when the weather was favourable for bee activity, i.e. with no or very little wind ( $<3$ on the Beaufort scale), when the visibility of a cloudless sky was at least about $70 \%$, and at temperatures in summer exceeding $16{ }^{\circ} \mathrm{C}$ (Krauss et al. 2009). All the sites were located at least $1.5 \mathrm{~km}$ apart. The specimens were mounted and identified to species level, except for bumblebees and easily distinguished species, which were identified alive during field research (McFrederick and Le Buhn 2006).

The names of species and information on their social behaviour (solitary, eusocial, cleptoparasitic), nesting sites (soil, hive, cavity), food preferences (oligolectic, polylectic), and body size (small $<8 \mathrm{~mm}$, medium $8-15 \mathrm{~mm}$, large $>15 \mathrm{~mm}$ ) follow Banaszak (1993), Celary (1995), Scheuchl (1995), Schmid-Egger and Scheuchl, (1997), Pesenko et al. (2002), Pawlikowski and Celary (2003), and Michener (2007) (Online Table A2). For each group, the number of species, the number of individuals, the percentage contributions to the total, and Shannon's index of diversity were calculated. 


\section{Environmental variables}

At each site, all plant species were recorded in areas including the transects analysed. Floristic surveys were carried out twice: in spring (May) and summer (July). On this basis we assessed the number of plant species (C1), the percentage of native plant species (C2), the percentage of alien plant species $(\mathbf{C 3})$, the percentage of annuals $(\mathbf{C 4})$. Simultaneously, we assessed the proportion (in percentage) of each site covered by shrubs and low trees $(\mathbf{C 5})$, grasses $>25 \mathrm{~cm}$ high (C6), grasses $<25 \mathrm{~cm}$ high (C7), blooming herbs (C8), and bare soil (C9). Additionally, we measured the total area of each wasteland $(\mathbf{C 1 0})$ on the basis of topographic maps on a scale of 1: 2000, using ArcGis software and direct field research.

Using a nominal scale, we also assessed: the degree of habitat isolation (C11) $0=$ open site, with only single shrubs/ trees, non forest or high buildings as flight barriers within $100 \mathrm{~m}, 1=$ single houses or allotments with built structures or dense shrubs/trees as low flight barriers within $100 \mathrm{~m}$. We calculated this variable based on the surrounding area of each cardinal direction (north, east, south and west) from of the site's borders. Each of the borders was sorted into one of two categories and was given respective points ranging from 0 to 1 . The points of all four directions were added up to obtain a single isolation score for each site with 0 being the lowest, and 4 being the highest possible score (after Fischer et al. 2016); habitat location (C12) $0=$ outside the edge zone of the Vistula valley (altitude $<60 \mathrm{~m}$ ), $1=$ within the edge zone (altitude $>60 \mathrm{~m}$ ), type of habitat management (C13) $0=$ lack of legal protection, $1=$ legal protection as a Landscape Park).

\section{Statistical analysis}

The species richness of Apiformes was assessed using rarefaction curves (Gotelli and Colwell 2001). The computations were performed with Estimates software (Colwell 2006). The extrapolated bee species richness (the number of observed species and the unobserved ones) was estimated using the Chao1 estimator (Chao 1984).

The species composition of Apiformes of individual types of wastelands was compared using Sørensen's coefficient (Sørensen 1948). The similarity of species composition and abundance was analysed on the basis of Morisita's overlap index (Horn 1966).

Numerical analysis of the collected data was performed using special software: CANOCO v. 4 (ter Braak and Šmilauer 1998) and MVSP 3.22 (Kovach 2002).

To determine which features of wastelands are crucial for their attractiveness to bees, we used the redundancy analysis (RDA: ter Braak and Šmilauer 1998). Selection of this method was linked with an earlier detrended correspondence analysis (DCA), which indicated linearity of the data used in the analysis (length of the gradient: 2.24 SD). Before statistical analysis, the dependent variable (species) was logtransformed $[\log (x)]$. To assess the significance of the tested variables and canonical axes, we performed a Monte Carlo permutation test with 1000 permutations. We assessed the influence of only statistically significant variables $(p<0.05)$. The collinearity of variables used in the RDA analysis was tested by calculating the VIF (Variance Inflation Factor) value. Only the variables for which the VIF was $<10$ were included in the model.

Generalized linear mixed models (GLMMs) were used to determine differences in the richness and abundance of bees in the suburbs and in residential/industrial districts. Spatial autocorrelation and temporal autocorrelation were verified using the F-test for nested models. The site and month were considered random effects and landscape type (suburbs vs. urban habitats) was considered a fixed effect. P-values were calculated using Wald's degrees of freedom method. The significance of spatial and temporal correlations was assessed with likelihood-ratio test comparing models with and without tested effect. Calculations were made in $\mathrm{R}$ package with the lme4 library (Bates et al. 2015; R Core Team 2017).

To determine the strength of relationship of a species with suburban or urban habitats, we calculated indicator values (IndVal) of bee species (Dufrêne and Legendre 1997). The IndVal method measures the strength of association of a given species with a given habitat on the basis of relative density and constancy of occurrence of the species in samples. If the IndVal was higher than 0.25 , the species was classified as strongly associated with the given habitat. The significance of IndVals was confirmed by a Monte Carlo test with 10,000 permutations. The above analyses were performed in the $\mathrm{R}$ software environment ( $\mathrm{R}$ Development Core Team 2017) with the use of libraries: vegan (Oksanen et al. 2011) and labdsv (Roberts 2010).

\section{Results}

\section{Species composition}

During this study, we recorded 201 species of wild bees (Hymenoptera: Apoidea) of 32 genera, in total 5915 individuals. They account for $42 \%$ of all bee species reported from Poland.

Apart from common species, we recorded also 36 species that are infrequent in Poland, including 23 species (11.4\%) that are red-listed in Poland (Banaszak 2002). They are classified as endangered (EN, one species: Andrena decipiens), vulnerable (VU, six species: Andrena falsifica, Anthocopa papaveris, Osmia cerinthidis, Bombus humilis, B. veteranus, 
Nomada opaca), least concern (LC, two species: Andrena curvungula, A. proxima) or of data deficient (DD, 15 species: Hylaeus bisinuatus, $H$. gracilicornis, $H$. paulus, $H$. styriacus, Andrena bimaculata, Halictus gavarnicus, $H$. semitectus, Sphecodes scabricollis, Anthidium oblongatum, Coelioxys alata, Hoplitis tridentata, Osmia xanthomelana, Ammobates punctatus, Bombus norvegicus, Nomada sheppardana) (Online Table A2).

Among the recorded bees, 11 species were dominants (each $>2 \%$ of the total catch) (Kasprzak and Niedbała 1981): Colletes fodiens, Andrena flavipes, Halictus sexcinctus, $H$. subauratus, Lasioglossum pauxillum, Dasypoda hirtipes, Melitta leporina, Osmia aurulenta, Anthophora bimaculata, Bombus pascuorum, and Tetraloniella dentata (Online Table A2). As many as 103 species (51.24\% of the total) were represented by $>10$ individuals, 26 species by single specimens in several wasteland types (12.93\%), and 44 $(21.89 \%)$ were found in only one type of wastelands (Online Table A2).

The most numerously represented families were the Halictidae (24.9\% of species, $24.9 \%$ of individuals), Apidae (22.9\% of species, $25.7 \%$ of individuals), and Megachilidae (20.9\% of species, $13.3 \%$ of individuals). In the studied communities, solitary bees accounted for $60.7 \%$ of the total species number (63.7\% of individuals), while cleptoparasitic bees for $24.9 \%$ of species and $11.3 \%$ of individuals. The least numerous were eusocial species (14.4\% of species, $25 \%$ of individuals). Most of the recorded bee species nested in the soil (49.3\% of species, $63.7 \%$ of individuals), were polylectic (55.7\% of species, $73.3 \%$ of individuals), and mediumsized $(69.7 \%$ of species, $72.4 \%$ of individuals). Bee species nesting above ground were much less numerous $(6.4 \%$ of species, $11.6 \%$ of individuals), and the same applies to largesized bees (2.9\% of species, $5.7 \%$ of individuals) (Online Table A2).

\section{Attractiveness of habitats}

The attractiveness of individual wasteland types was assessed on the basis of the observed number of bee species and estimates made using the Chao 1 estimator. The most attractive to bees were the wastelands resulting from extractive industry [C], where 143 species were recorded, followed by grassy habitats located in the suburbs [A, B], with 137 and 117 species of bees, respectively (Online Table A2). The estimated numbers of bees in those habitat types were 160 , 142 , and 129, respectively. The least attractive to bees were the habitats directly influenced by chemical industry [G], where only 49 bee species were found (estimated number: 70). Similar relationships were observed also for the number of species and Shannon's diversity index, i.e. wastelands
A-C were characterized by the highest values of the analysed indices, while types E-G by the lowest values (Online Table A2).

\section{Similarity of communities}

The analysis of qualitative similarity (Fig. 4) of bee communities (Sorensen's coefficient) has revealed that their similarity between the analysed habitat types exceeds 50\% as a rule. The wastelands in areas directly influenced by chemical industry were exceptional in this respect, as their similarity to the other types was about $40 \%$. Qualitatively 3 habitat types were the most similar to grasslands in the suburbs (the least disturbed habitats): degraded grasslands closer to the city centre (similarity 0.780 ), extraction pits and their vicinity (similarity 0.760 ), and old fields (similarity 0.698) (Table 1, Fig. 4).

The analysis of quantitative similarity of Apiformes (Morisita's overlap index) (Fig. 4) also revealed that the most distinct bee communities of wastelands were those directly affected by chemical industry or located in the former military training area. Their similarity to the other habitat types was in most cases lower than 50\%. Quantitatively, the same three habitat types were the most similar to grasslands in the suburbs: degraded grasslands closer to the city centre (similarity 0.687 ), extraction pits and their vicinity (similarity 0.772 ), and old fields (similarity 0.551) (Table 1, Fig. 4).

\section{Factors that influence species distribution}

Using RDA, we identified which features of the wastelands influence most strongly their attractiveness to wild bees. After excluding statistically non-significant variables (grasses $>25 \mathrm{~cm}$ high, bare soil), the collinearity of the data was tested. The VIF factor was $>10$ for the following parameters, which were excluded from further analysis: the number of plant species, the percentage of native plant species. The occurrence of species was significantly affected by 9 variables: coverage of shrubs and low trees (C5), location (C12), degree of isolation (C11), percentage of annuals (C4), percentage of alien species (C3) ( $p=0.001$ in each cases), coverage of blooming herbs (C8) $(p=0.002)$, management $(\mathrm{C} 13)(p=0.006)$, grasses $<25 \mathrm{~cm}$ high $(\mathrm{C} 7)(p=0.029)$, and area of the wasteland (C10) $(p=0.039)$ (Fig. 5). The occurrence of most of the species was negatively correlated with the increasing isolation of wastelands and increasing contributions of alien species, annuals, and grasses $<25 \mathrm{~cm}$ high, while positively with the other factors (Fig. 5). Values 
Fig. 4 Qualitative and quantitative similarity (Sorensen's coefficient and Morisita's overlap index, respectively) of wild bee communities in the analysed wasteland types

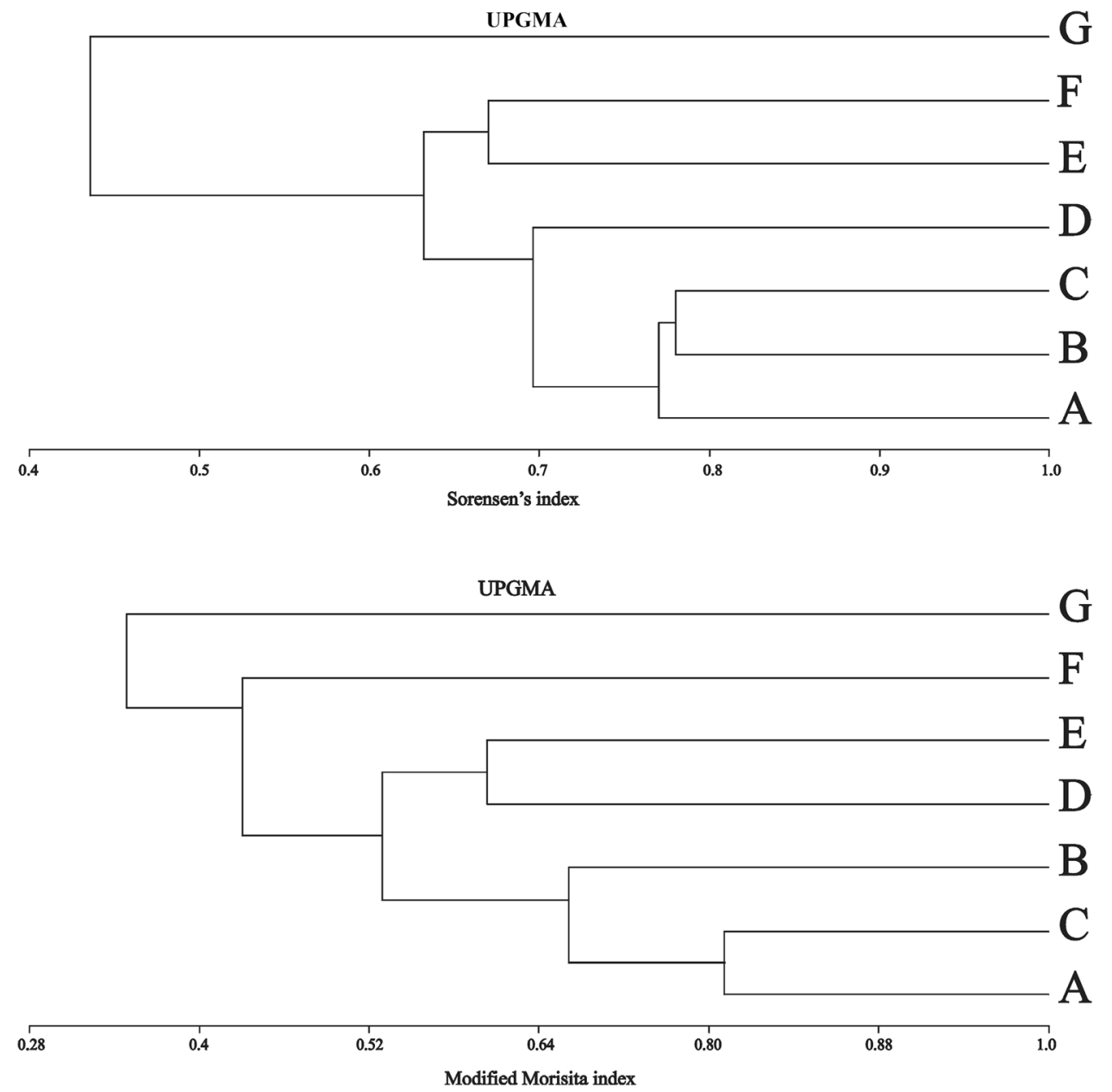

Table 1 Similarity between the seven analysed wasteland types in bee species composition (Sørensen's coefficient) and the abundance of individuals (Morisita's overlap index)

\begin{tabular}{|c|c|c|c|c|c|c|c|c|c|c|c|c|c|c|c|}
\hline \multirow[t]{2}{*}{ Habitat } & \multicolumn{7}{|c|}{ Sorensen } & \multirow[t]{2}{*}{ Habitat } & \multicolumn{7}{|c|}{ Morisita-Horn } \\
\hline & A & B & $\mathrm{C}$ & $\mathrm{D}$ & $\mathrm{E}$ & $\mathrm{F}$ & $\mathrm{G}$ & & A & B & $\mathrm{C}$ & $\mathrm{D}$ & $\mathrm{E}$ & $\mathrm{F}$ & G \\
\hline A & 1 & & & & & & & A & 1 & & & & & & \\
\hline B & 0.780 & 1 & & & & & & B & 0.687 & 1 & & & & & \\
\hline $\mathrm{C}$ & 0.760 & 0.780 & 1 & & & & & $\mathrm{C}$ & 0.772 & 0.636 & 1 & & & & \\
\hline $\mathrm{D}$ & 0.698 & 0.708 & 0.684 & 1 & & & & $\mathrm{D}$ & 0.551 & 0.520 & 0.616 & 1 & & & \\
\hline E & 0.656 & 0.696 & 0.618 & 0.673 & 1 & & & E & 0.445 & 0.469 & 0.573 & 0.604 & 1 & & \\
\hline $\mathrm{F}$ & 0.615 & 0.577 & 0.558 & 0.659 & 0.670 & 1 & & $\mathrm{~F}$ & 0.416 & 0.362 & 0.463 & 0.459 & 0.454 & 1 & \\
\hline G & 0.441 & 0.458 & 0.419 & 0.444 & 0.449 & 0.406 & 1 & G & 0.513 & 0.439 & 0.406 & 0.327 & 0.263 & 0.146 & 1 \\
\hline
\end{tabular}

Sites A—degraded grasslands in the suburbs; B—degraded grasslands closer to the city centre; C—clay and sand quarries; D—old fields; Esites where industrial buildings or warehouses had been demolished; F-wastelands in a former military training area; G-wastelands directly affected by chemical industry

of indices describing the structure of bee communities in individual types of wastelands and detailed characteristics of their vegetation structure (= environmental variables) are presented in Table 2.

\section{Changes in the richness and abundance of bees: suburbs versus urban habitats}

The analysis has shown significantly higher richness $(p=0.004)$ and abundance $(p<0.001)$ of bees in wastelands 
Fig. 5 Ordination diagram based on the redundancy analysis (RDA), presenting the distribution of wild bee species with respect to the first 2 axes, and vectors of significant variables. All the variables used in the analysis explained $74.4 \%$ of the variation in Apiformes species data (sum of all canonical eigenvalues: 0.744; sum of all eigenvalues: 1.000; $0.744 / 1.000=0.744$, i.e. $74.4 \%$ )

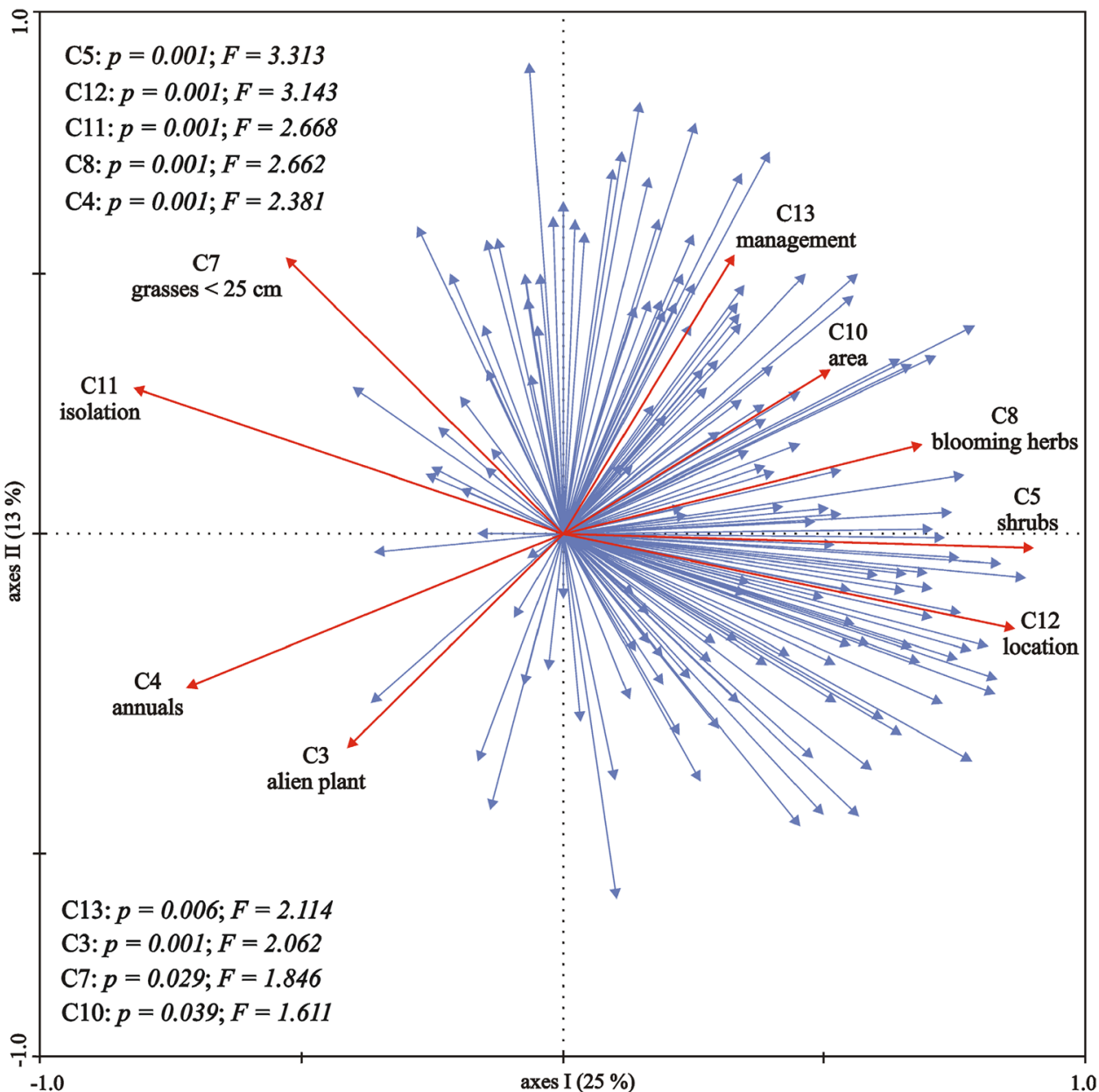

\begin{tabular}{|c|c|c|c|c|c|c|c|c|c|c|c|c|c|}
\hline \multirow[t]{3}{*}{ Site } & \multicolumn{3}{|c|}{ Bee community } & \multicolumn{9}{|l|}{ Plant } & \multirow{3}{*}{$\begin{array}{l}\text { C10 } \\
\text { (ha) }\end{array}$} \\
\hline & \multirow[t]{2}{*}{$\mathrm{R}$} & \multirow[t]{2}{*}{$\mathrm{A}$} & \multirow[t]{2}{*}{$\mathrm{D}$} & \multirow[t]{2}{*}{ Total } & \multicolumn{3}{|c|}{$\%$ of species at this site } & \multicolumn{5}{|c|}{$\%$ of area covered } & \\
\hline & & & & & Native & Alien & Annuals & $\mathrm{C} 5$ & C6 & C7 & C8 & C9 & \\
\hline \multirow[t]{2}{*}{ A } & 117 & 945 & 4.106 & 63 & 80 & 17 & 11 & 20 & 40 & 10 & 30 & 0 & 24 \\
\hline & 93 & 692 & 3.652 & 80 & 81 & 19 & 15 & 30 & 30 & 5 & 30 & 0 & 13 \\
\hline \multirow[t]{2}{*}{ B } & 91 & 602 & 3.903 & 64 & 84 & 16 & 14 & 40 & 10 & 20 & 30 & 0 & 21 \\
\hline & 81 & 449 & 3.801 & 33 & 83 & 18 & 18 & 10 & 10 & 35 & 30 & 15 & 7 \\
\hline \multirow[t]{2}{*}{$\mathrm{C}$} & 105 & 708 & 4.089 & 66 & 77 & 23 & 20 & 15 & 0 & 25 & 30 & 30 & 35 \\
\hline & 93 & 467 & 3.962 & 60 & 80 & 18 & 20 & 15 & 30 & 10 & 25 & 20 & 5 \\
\hline \multirow[t]{2}{*}{$\mathrm{D}$} & 71 & 400 & 3.684 & 43 & 77 & 23 & 16 & 5 & 20 & 50 & 15 & 10 & 11 \\
\hline & 54 & 193 & 3.588 & 31 & 74 & 26 & 26 & 5 & 65 & 15 & 10 & 5 & 15 \\
\hline \multirow[t]{2}{*}{ E } & 88 & 401 & 3.978 & 46 & 74 & 26 & 26 & 5 & 30 & 30 & 15 & 20 & 2 \\
\hline & 50 & 211 & 3.434 & 32 & 75 & 25 & 19 & 10 & 20 & 45 & 10 & 15 & 2 \\
\hline \multirow[t]{2}{*}{ F } & 74 & 437 & 3.685 & 47 & 75 & 26 & 21 & 10 & 5 & 40 & 20 & 30 & 8 \\
\hline & 40 & 186 & 3.262 & 34 & 71 & 20 & 21 & 0 & 30 & 55 & 5 & 15 & 24 \\
\hline \multirow[t]{2}{*}{ G } & 33 & 81 & 3.231 & 31 & 52 & 48 & 29 & 0 & 80 & 10 & 5 & 5 & 6 \\
\hline & 27 & 143 & 2.694 & 19 & 58 & 42 & 37 & 0 & 65 & 30 & 5 & 0 & 5 \\
\hline
\end{tabular}

$R$ species richness, $A$ abundance (number of individuals per site), $D$ diversity (Shannon's index), $C 5$ coverage of shrubs, $C 6$ coverage of grasses $>25 \mathrm{~cm}$ high, $C 7$ coverage of grasses $<25 \mathrm{~cm}$ high, $C 8$ coverage of blooming herbs, $C 9$ bare soil, $C 10$ area of the wasteland 
Table 3 Effects of landscape type (suburbs vs. urban) on the richness and abundance of wild bees

\begin{tabular}{|c|c|c|c|c|c|}
\hline \multirow[t]{2}{*}{ Functional trait } & \multirow[t]{2}{*}{ Suburbs } & \multirow[t]{2}{*}{ Urban } & \multicolumn{3}{|c|}{ Suburbs versus urban habitats } \\
\hline & & & Estimate $\pm \mathrm{CI}$ & $\mathrm{z}$ & $\mathrm{p}$ \\
\hline \multicolumn{6}{|l|}{ Richness } \\
\hline Total & $83.83 \pm 10.91$ & $55.00 \pm 8.74$ & $-18.40 \pm 12.54$ & -2.88 & 0.004 \\
\hline \multicolumn{6}{|l|}{ Behaviour } \\
\hline Solitary & $51.60 \pm 8.60$ & $30.33 \pm 5.17$ & $-11.80 \pm 7.52$ & -3.08 & 0.002 \\
\hline Eusocial & $16.17 \pm 2.30$ & $12.66 \pm 1.76$ & $-3.93 \pm 2.92$ & -2.64 & 0.008 \\
\hline Cleptoparasitic & $14.16 \pm 2.89$ & $12.00 \pm 2.06$ & $-2.67 \pm 3.60$ & -1.45 & 0.174 \\
\hline \multicolumn{6}{|l|}{ Nest substrate } \\
\hline Soil & $46.83 \pm 5.85$ & $27.50 \pm 3.78$ & $-12.53 \pm 6.83$ & -3.60 & $<0.001$ \\
\hline Hive & $7.00 \pm 1.09$ & $6.16 \pm 1.01$ & $-1.20 \pm 1.61$ & -1.46 & 0.145 \\
\hline Cavity & $13.50 \pm 4.12$ & $9.33 \pm 2.70$ & $-2.00 \pm 2.79$ & -1.40 & 0.160 \\
\hline \multicolumn{6}{|l|}{ Floral specificity } \\
\hline Oligolectic & $12.50 \pm 3.92$ & $8.83 \pm 2.56$ & $-1.73 \pm 2.28$ & -1.49 & 0.136 \\
\hline Polylectic & $54.83 \pm 6.96$ & $28.16 \pm 6.73$ & $-14.00 \pm 8.24$ & -3.33 & 0.001 \\
\hline \multicolumn{6}{|l|}{ Body size } \\
\hline Small $(<8 \mathrm{~mm})$ & $21.66 \pm 3.48$ & $14.16 \pm 2.89$ & $-4.60 \pm 3.54$ & -2.55 & 0.011 \\
\hline Medium (8-15 mm) & $59.50 \pm 7.28$ & $38.33 \pm 5.70$ & $-12.87 \pm 8.86$ & -2.85 & 0.004 \\
\hline Large $(>15 \mathrm{~mm})$ & $2.66 \pm 0.33$ & $2.50 \pm 0.50$ & $-0.93 \pm 0.74$ & -2.47 & 0.014 \\
\hline \multicolumn{6}{|l|}{ Abundance } \\
\hline Total & $644.00 \pm 124.72$ & $304.66 \pm 80.68$ & $-135.73 \pm 76.27$ & -3.49 & $<0.001$ \\
\hline \multicolumn{6}{|l|}{ Behaviour } \\
\hline Solitary & $409.66 \pm 76.00$ & $200.33 \pm 54.22$ & $-83.73 \pm 46.22$ & -3.55 & $<0.001$ \\
\hline Eusocial & $165.66 \pm 49.47$ & $68.50 \pm 20.51$ & $-38.87 \pm 27.22$ & -2.80 & 0.005 \\
\hline Cleptoparasitic & $68.66 \pm 4.96$ & $35.83 \pm 11.90$ & $-13.13 \pm 12.62$ & -2.04 & 0.041 \\
\hline \multicolumn{6}{|l|}{ Nest substrate } \\
\hline Soil & $437.00 \pm 86.82$ & $136.00 \pm 50.53$ & $-12.53 \pm 6.83$ & -3.60 & $<0.001$ \\
\hline Hive & $56.66 \pm 24.85$ & $47.16 \pm 18.23$ & $-3.80 \pm 10.52$ & -0.71 & 0.479 \\
\hline Cavity & $81.66 \pm 18.85$ & $49.00 \pm 15.16$ & $-13.07 \pm 13.05$ & -1.90 & 0.058 \\
\hline \multicolumn{6}{|l|}{ Floral specificity } \\
\hline Oligolectic & $89.33 \pm 39.60$ & $53.16 \pm 21.82$ & $-11.47 \pm 15.08$ & -1.49 & 0.136 \\
\hline Polylectic & $486.00 \pm 88.30$ & $208.16 \pm 52.87$ & $-111.13 \pm 60.16$ & -3.62 & $<0.001$ \\
\hline \multicolumn{6}{|l|}{ Body size } \\
\hline Small (<8 mm) & $155.66 \pm 35.81$ & $56.16 \pm 19.36$ & $-39.80 \pm 26.18$ & -2.98 & 0.003 \\
\hline Medium (8-15 mm) & $461.11 \pm 79.75$ & $232.83 \pm 57.35$ & $-91.40 \pm 51.95$ & -3.45 & 0.001 \\
\hline Large $(>15 \mathrm{~mm})$ & $27.00 \pm 14.06$ & $15.66 \pm 6.34$ & $-4.53 \pm 5.99$ & -1.48 & 0.138 \\
\hline
\end{tabular}

The table shows the results of linear mixed models GLMMs, taking into account spatial and temporal correlations among collected data; bold estimates indicate significant effects at $\mathrm{p}<0.05$ located in the suburbs, compared to residential/industrial districts (Table 3).

In the suburbs, the proportion of the following species categories increased with regard to richness: solitary $(p=0.002)$, eusocial $(p=0.008)$, nesting in the soil $(p<0.001)$, polylectic $(p=0.001)$. Also, in the case of all species belonging to the distinguished size categories (small, $p=0.011$; medium, $p=0.004$; large, $p=0.014$ ), the richness increased in environments on the outskirts of the city (Table 3). However, no differences were found for cleptoparasitic, hive, cavity and oligolectic species.

Similar correlations were found in species abundance. However, in this case, no additional differences were found for species with large body size (Table 3). 
Table 4 Associations of individual species with the studied habitats (suburbs, urban habitats): statistically significant indicator values IndVal $>0.25$ for individual bee species

\begin{tabular}{|c|c|c|c|c|c|c|}
\hline \multirow[t]{2}{*}{ Species } & \multirow[t]{2}{*}{ IndVal } & \multirow[t]{2}{*}{$p$} & \multicolumn{2}{|l|}{ Suburbs } & \multicolumn{2}{|c|}{ Urban habitats } \\
\hline & & & Abundance & Frequency & Abundance & Frequency \\
\hline Andrena flavipes & 0.804 & 0.018 & 259 & 100.00 & 63 & 83.33 \\
\hline Halictus sexcinctus & 0.853 & 0.028 & 105 & & 18 & 66.66 \\
\hline Melitta leporina & 0.850 & 0.042 & 125 & & 22 & \\
\hline Nomada fucata & 0.910 & 0.020 & 61 & & 6 & 50.00 \\
\hline Andrena falsifica & 0.890 & 0.007 & 65 & & 8 & 33.33 \\
\hline Megachile circumcincta & 0.833 & 0.020 & 20 & & 4 & \\
\hline Andrena ventralis & 0.976 & 0.006 & 42 & & 1 & 16.66 \\
\hline Halictus leucaheneus & 0.954 & 0.007 & 21 & & 1 & \\
\hline Andrena subopaca & 0.950 & 0.006 & 19 & & 1 & \\
\hline Lasioglossum laevigatum & 0.945 & 0.006 & 52 & & 3 & \\
\hline Halictus quadricinctus & 0.750 & 0.023 & 18 & 83.33 & 2 & 33.33 \\
\hline Andrena nigroaenaea & 0.801 & 0.017 & 25 & & 1 & 16.66 \\
\hline Andrena fulvago & 0.773 & 0.029 & 13 & & 1 & \\
\hline Lasioglossum majus & 0.833 & 0.019 & 73 & & - & - \\
\hline Nomada succincta & 0.833 & 0.015 & 25 & & - & - \\
\hline Andrena gravida & 0.833 & 0.019 & 18 & & - & - \\
\hline Hylaeus gibbus & 0.880 & 0.019 & 3 & 33.33 & 22 & 100.00 \\
\hline
\end{tabular}

\section{Indicator species: suburbs versus urban habitats}

We identified 17 indicator species (IndVal method), and nearly all of them (16: Andrena falsifica, A. flavipes, A. fulvago, A. gravida, A. nigroaenaea, A. subopaca, A. ventralis, H. leucaheneus, H. sexcinctus, H. quadricinctus, Lasioglossum laevigatum, L. majus, Megachile circumcincta, Melitta leporina, Nomada fucata, $N$. succincta) were associated with suburbs, while only one species (Hylaeus gibbus) was associated with urban habitats. The abundance of indicator species linked with suburbs varied from 13 to 259 individuals per site, while frequency, from $83.3 \%$ to $100 \%$ (Table 4).

The genus Andrena was represented by the largest number of indicator species. Numbers of species of this and other genera were similar in urban and suburban habitats (Table 4).

\section{Discussion}

In spite of the potentially negative effects of urbanization, towns and cities play an important role in shaping the species diversity of Apiformes (McIntyre and Hostetler 2001). For example, one-third of the known bee species of France were recorded in Lyon (Fortel et al. 2014), about 262 bee species in Berlin, Germany (Saure 1996), 110 species in New York, USA (Fetridge et al. 2008), while in Poland 206 in Poznań (Banaszak-Cibicka and Banaszak 2011), 203 in Łódź (Kowalczyk et al. 2008) and previous research in Bydgoszcz 197 (Banaszak 2008).
The results of this study show that some types of urban wastelands can be important habitats for wild bees. This is evidenced not only by the high species diversity and abundance of bees, but also the presence of rare species, including 23 red-listed ones. Their presence indicates the role of the analysed habitats in nature conservation. Results of other European studies also confirm that urban wastelands are characterized by high species richness, in most cases, they can harbour more species than other urban green spaces (Eyre et al. 2003; Small et al. 2003; Bonthoux et al. 2014).

\section{Ecological characteristics of species found in wastelands}

We found that a majority of the bee species recorded at the study sites were solitary. At the same time, the number of eusocial species was comparable to that reported in another study (Banaszak-Cibicka et al. 2018). However, the contribution of cleptoparasitic species was relatively high (25\% of the total). Cleptoparasites usually constitute approx. $15-20 \%$ of species in bee assemblages (Wcislo and Cane 1996). It is assumed that in stable assemblages the ratio of parasites is higher (Calaburg 2000). Lack of parasites or their low ratio in the community points to the instability of the host species population. This may stem from the host population being newly founded or characterized by large fluctuations in abundance. It may also be caused by the fact that the presence of the host species is ephemeral and does not result from nesting in a given place. According to Cane (2005), cleptoparasitic species are very rare in urban environments. This has been confirmed in studies conducted in 
parks and gardens in Poznań - 12.5\% (Banaszak-Cibicka and Żmihorski 2012) and in gardens in New York-5.6\% (Matteson et al. 2008). The high ratio of cleptoparasitic species in the wastelands studied indirectly indicates that these habitats offer convenient living conditions for large and stable populations of host species (Cierzniak 2003).

In this study, polylectic species prevailed, using various plant species as sources of food. This pattern is consistent with the patterns reported from other urban ecosystems (Fetridge et al. 2008; Matteson et al. 2008; Tonietto et al. 2011; Banaszak-Cibicka and Żmihorski 2012). Simultaneously, the number of recorded oligolectic species was also relatively high, which may result from the specific location of Bydgoszcz. It is situated at the edges of the Vistula valley, whose slopes are partly covered with xerothermic and sandy grasslands. Since sheep grazing was discontinued there (about 20 years ago), the habitats are subject to gradual degradation, associated with ecological succession on the slopes. However, some rare thermophilous plant species are still found there, e.g. Campanula sibirica or Salvia pratensis.

Beside food resources, another factor affecting bee diversity is the availability of suitable nesting sites and substrates (Potts et al. 2005). Many bee species nesting in the ground prefer permeable sandy or loamy soils, with good light conditions (Cane 1991), which dominated in the analysed areas. That is why ground-nesting species were also abundant in the studied communities.

\section{Attractiveness of wastelands}

Urban wastelands are often distinguished by the composition of their flora and fauna. Such a different species composition is modified both by the spontaneous dynamics of nature and the history of land use at individual sites. In the present study, bee communities in most of the analysed wastelands showed high similarity, both qualitative and quantitative. The most attractive to bees were the wastelands resulting from extractive industry. Also, earlier studies showed that sand pits or gravel pits are important habitats readily colonized by various insect species, including rare ones, with specific environmental or food requirements (Lönnberg and Jonsell 2012; Heneberg et al. 2013). Quarries belong to specific environments in the landscape with bare soil patches maintained by regular human disturbances and occupied mainly by synanthropic vegetation. Excavations modify the existing habitat conditions and lead to more varied terrain, thus increasing the availability of diverse microhabitats for nesting and appropriate food plants. In contrast, the most distinct and the least attractive to bees were the habitats directly influenced by chemical industry, as they were characterized by the lowest floristic diversity and a high contribution of alien plant species as a measure of habitat transformation.

\section{Factors explaining wasteland biodiversity}

Urban wastelands, in contrast to managed parks and gardens, are usually dominated by ruderal plant species (Martins et al. 2017). Many of them, e.g. Arctium lappa, Ballota nigra, Echium vulgare, Malva neglecta, Ranunculus repens or Sonchus arvensis, are bee forage plants. Moreover, their existence in wastelands ensures continuity of food resources for bees. Since bees are completely dependent on plant food, the diversity and abundance of blooming plants are dominant factors shaping the natural resources of bees.

Our results show that the location of some study sites in the suburbs at the edges of the Vistula valley or outside the valley, in industrial zones, was one of the major factors significantly affecting the occurrence of species. Peri-urban areas can support very diverse pollinator assemblages and can have the source role for animal populations in cities (Hinners et al. 2012). Suburban insect assemblages can be even comparable to the natural areas, but this capacity is strongly affected by local habitat quality. However, the major factors increasing the natural resources of bees were coverage of blooming herbs as well as shrubs and low trees. Our findings are partly consistent with the results of other studies. There is no doubt that the increase in abundance of blooming plants has a positive influence on bee diversity (Steffan-Dwenter and Tscharntke 2000; Kearns and Oliveras 2009), but an increase in coverage of shrubs is not always positively correlated with an increase in bee diversity (Banaszak-Cibicka et al. 2016). In our study, a significant role as a source of bee forage in spring was played by a shrub community composed of many species (Rubo fruticosi-Prunetum spinosae), including mostly low shrubs, e.g. Prunus spinosa and species of the genera Crataegus, Rubus, Euonymus, Lonicera, and Ribes. Patches of this community usually develop on potential sites of former oak-hornbeam forests, in less accessible places that are not used by agriculture (crests of hills, steep slopes). This plant community is also characteristic of edges of railway routes, roads, and industrial areas. It seems that in our study the presence of small wooded patches rich in nectar- and pollen-producing species, not only enriched their food resources but also increased the heterogeneity of the habitat, which is a significant factor determining the natural resources of Apiformes (Meyer et al. 2007; Diacon-Bolli et al. 2012). Nevertheless, no significant relationship was observed between the percentage contribution of bare soil and bee diversity. We found, however, that the sites covered with low grasses, e.g. Corynephorus canescens L., were not preferred by bees, which could be related to limited food resources in such places. 


\section{Factors influencing species distribution}

We found that post-industrial wastelands, old fields, and areas where buildings had been demolished with a high diversity of native flowering plants were attractive to bees regardless of their location (suburbs vs. urban areas). Thus our findings suggest that some of the degraded areas can also serve as favourable habitats for wildlife, and contribute to the creation of the network of urban green areas. Similar conclusions have also been drawn by Threlfall et al. (2015) and Tommasi et al. (2004), who reported that marginal habitats are important for the protection of wild bees in urban ecosystems. When planning the possible use and inclusion of such habitats in the overall environmental balance of the city, it is necessary to take into account their sizes, connections with other green areas, and to assess the degree of their degradation. We found that an increase in isolation of the habitat patches, and transformations of habitats (measured on the basis of the contribution of alien species to plant communities) were negatively correlated with the number and abundance of wild bees, while positively with the size of wastelands. Similar conclusions have been drawn also by other researchers (Cierzniak 2003; Fischer et al. 2016), who indicated that the isolation and size of habitats are some of the major factors limiting the resources of bees. The proximity of attractive green areas facilitates the penetration of species into cities and the exchange of species between populations. The greater the distance between these areas, the more difficult it is for the bees to move between them. This is particularly important for small bee species that do not cover large distances to forage or find suitable nesting sites. Since the flight range is related to the size of the body (Westrich 1989; Greenleaf et al. 2007), the ranges vary depending on the species (Gathmann and Tscharntke 2002; Knight et al. 2005; Wojcik and McBride 2012). Therefore, links between habitats are considered an important factor increasing biodiversity (Niemelä 1999; Savard et al. 2000).

\section{Suburbs versus urban areas}

Our research has shown a significantly higher richness and abundance of bees in wastelands located in suburbs compared to the urban areas. Among the species associated with the suburbs, solitary bees nesting in the soil and using various species of flowering plants were the most abundant group. At the same time, there were no differences in the richness of cleptoparasitic species found in the two zones compared. Differences were, however, observed in their abundance. The higher abundance of parasitic species in the suburbs probably resulted from the fact that most of the identified species were cleptoparasitic bees of the genus Andrena, which particularly preferred habitats located on the outskirts of the city. Similarly, there were no differences in species richness and abundance oligolectic species between the zones studied. This is probably related to the high occurrence of synanthropic (often ruderal) plant species from the Asteraceae, Fabaceae and Lamiaceae families in urban habitats. These species are attractive for oligolectic bees associated with a given type of flowering plants.

A comparison of percentage contributions of individual species in urban and suburban habitats shows that out of the 17 species with a high constancy of occurrence, as many as 16 were associated with the suburbs, and only one, Hylaeus gibbus, was characteristic of urban wastelands. The large number of indicator species found in the suburbs suggests that living conditions for bees in those habitats are much more favourable than in urban ones. In this context, we suggest that the managers of those areas should pay special attention to the maintenance of a proper structure of their vegetation.

\section{Recommendations for conservation and management}

Undoubtedly a lack of management in wastelands (Gardiner et al. 2014) increases the stability of native flora, often replaced in revitalized parks by ornamental exotic species of cultivated plants, but does not improve the condition of habitats threatened with ecological succession, which in temperate climate is always directed towards formation of shrub communities followed by forests (Bornkamm 2006). Forest communities of the temperate zone are characterized by a lower diversity of Apiformes than sunny open habitats. Hence, the recommended vegetation structure is grasslands with small patches of shrubs and low trees, which enable survival of species with various environmental requirements.

The EU Biodiversity Strategy to 2020 (European Union 2011) assumes that the improvement of knowledge of ecosystems and their services in the EU can help to maintain nature in good condition. One of the targets of this Strategy is to maintain and restore ecosystems and their services by establishing green infrastructure. It seems that the appreciation of the role of some types of wastelands in any European countries can be a chance to increase the range of services, especially of regulatory services (e.g. pollination by insects) or cultural ones (e.g. possibility of recreation, tourism, aesthetic values). Wastelands can be included in urban planning schemes as temporary locations and new types of urban greenery (Kowarik 2011). Examples of such actions can be found in Leipzig (Rall and Haase 2011) and Berlin (Kowarik and Langer 2005). To achieve this target, public opinion and decision-makers should start to treat wastelands as parts of the urban ecosystem (Threlfall and Kendal 2018). The increasing environmental awareness of the society may help to promote the proper management of such areas so that both 
people and animals could use the same green areas (Middle et al. 2014; Goddard et al. 2009).

\section{Conclusions}

Although the environmental value of wastelands is appreciated more and more often (Fischer et al. 2016), so far they have been rarely intentionally used to support urban biodiversity. Undoubtedly proper planning of urban space should be based not only on designating urban wastelands for residential development but also on taking into account the benefits resulting from various types of land use, which fulfil various ecosystem functions. Urban wastelands are characterized by high variability, resulting from land use in the past, location in the landscape, and successional transformations. Our results show that some types of wastelands can be environmentally valuable spaces and should be cared for, very much like urban managed green areas.

Acknowledgements We thank the anonymous reviewers for very helpful suggestions which considerably improved the quality of this paper.

Funding This study was partly supported by the Polish Minister of Science and Higher Education, under the program "Regional Initiative of Excellence" in 2019-2022 (Grant No. 008/RID/2018/19).

\section{Compliance with ethical standards}

Conflict of interest The authors declare that they have no conflict of interest.

Open Access This article is distributed under the terms of the Creative Commons Attribution 4.0 International License (http://creativeco mmons.org/licenses/by/4.0/), which permits unrestricted use, distribution, and reproduction in any medium, provided you give appropriate credit to the original author(s) and the source, provide a link to the Creative Commons license, and indicate if changes were made.

\section{References}

Albrecht M, Duelli P, Schmid B, Muller CB (2007) Interaction diversity within quantified insect food webs in restored and adjacent intensively managed meadows. J Anim Ecol 76:1015-1025. https ://doi.org/10.1111/j.1365-2656.2007.01264.x

Aronson MF, La Sorte FA, Nilon CH, Katti M, Goddard MA et al (2014) A global analysis of the impacts of urbanization on bird and plant diversity reveals key anthropogenic drivers. Proc $\mathrm{R}$ Soc Lond B Biol Sci 281:2013-3330. https://doi.org/10.1098/ rspb.2013.3330

Banaszak J (1980) Studies on methods of censusing the numbers of bees (Hymenoptera, Apoidea). Pol Ecol Studies 6(2):355-366 Record Number: 19810212170

Banaszak J (1993) Trzmiele Polski. Wyd. Uczelniane WSP w Bydgoszczy, Bydgoszcz
Banaszak J (2002) Apoidea pszczoły. In: Głowaciński Z (ed) Red list of threatened animals in Poland. Instytut Ochrony Przyrody PAN, Kraków, pp 69-75

Banaszak J (2008) Fauna of bees (Hymenoptera: Apoidea: Apiformes) of Bydgoszcz. In: Indykiewicz P, Jerzak L, Barczak T (eds) Fauna miast. Ochronić różnorodność biotyczną w miastach. SAR "Pomorze", Bydgoszcz, pp 234-245

Banaszak-Cibicka W, Banaszak J (2011) Pollinating insects of cities (Hymenoptera: Apoidea: Apiformes). Part I. Fauna of Poznań in comparison with bees of other polish cities. In: Indykiewicz P, Jerzak L, Böhner J, Kavanagh B (eds) Urban fauna. Studies of animal biology, ecology and conservation in European cities. UTP, Bydgoszcz, pp 227-236

Banaszak-Cibicka W, Żmihorski M (2012) Wild bees along an urban gradient: winners and losers. J Insect Conserv 16:331-343. https ://doi.org/10.1007/s10841-011-9419-2

Banaszak-Cibicka W, Ratyńska H, Dylewski Ł (2016) Features of urban green space favourable for large and diverse bee populations (Hymenoptera: Apoidea: Apiformes). Urban For Urban Gree 20C:448-452. https://doi.org/10.1016/j.ufug.2016.10.015

Banaszak-Cibicka W, Twerd L, Fliszkiewicz M, Giejdasz K, Langowska A (2018) City parks vs. natural areas-is it possible to preserve a natural level of bee richness and abundance in a city park? Urban Ecosyst 21:599-613. https://doi.org/10.1007/s1125 2-018-0756-8

Bates D, Maechler M, Bolker B, Walker S (2015) Fitting linear mixedeffects models using lme4. J Stat Softw 67(1):1-48

Bonthoux S, Brun M, Di Pietro F, Greulich S, Bouché-Pillon S (2014) How can wastelands promote biodiversity in cities? A review. Landsc Urban Plann 132:79-88

Bornkamm R (2006) Fifty years vegetation development of a xerothermic calcareous grassland in Central Europe aft er heavy disturbance. Flora 201:249-267. https://doi.org/10.1016/j.flora .2005 .06 .012

Calaburg I (2000) Solitary bees and bumble bees in a Danish agricultural landscape. Ph. D. thesis. Dept. Popul. Ecol. Univ. Copenhagen

Cane JH (1991) Soils of ground-nesting bees (Hymenoptera: Apoidea): Texture, moisture, cell depth and climate. J Kansas Entomol Soc 4:406-413

Cane JH (2005) Bees, pollination, and the challenges of sprawl. In: Johnson EA, Klemens MW (eds) Nature in fragments: the legacy of sprawl. Columbia University Press, New York, pp 109-124

Carper AL, Adler LS, Warren SW, Irwin RE (2014) Effects of suburbanization on forest bee communities. Environ Entomol 43(2):253-262. https://doi.org/10.1603/EN13078

Celary W (1995) Nomadini (Hymenoptera, Apoidea, Anthophoridae) of Poland. Polish Academy of Sciences, Poznan, p 281

Chao A (1984) Non-parametric estimation of the number of classes in a population. Scand J Stat 11:265-270

Cierzniak T (2003) Ekologia pszczół w dynamicznym kręgu zbiorowisk grądowych. Bydgoszcz, Poland

Colla SR, Willis E, Packer L (2009) Can green roofs provide habitat for urban bees (Hymenoptera: Apidae)? Cities Environ 2(1):1-12

Colwell RK (2006) EstimateS: Statistical estimation of species richness and shared species from sample. Version 8.0.0. User's Guide and applications published at: http://purl.oclc.org/estimates

Concepción ED, Moretti M, Altermatt F, Nobis MP, Obrist MK (2015) Impacts of urbanisation on biodiversity: the role of species mobility, degree of specialisation and spatial scale. Oikos 124:1571-1582. https://doi.org/10.1111/oik.02166

Diacon-Bolli J, Dalang T, Holderegger R, Bürgi M (2012) Heterogeneity fosters biodiversity: linking history and ecology of dry calcareous grasslands. Basic Appl Ecol 13:641-653. https://doi. org/10.1016/j.baae.2012.10.004 
Dufrêne M, Legendre P (1997) Species assemblages and indicator species: the need for a flexible asymmetrical approach. Ecol Monogr 67:345-366. https://doi.org/10.1890/00129615(1997)067\%5b0345:SAAIST\%5d2.0.CO;2

Eckert S, Möller M, Buchholz S (2017) Grasshopper diversity of urban wastelands is primarily boosted by habitat factors. Insect Conserv Diver. https://doi.org/10.1111/icad.12221

European Union (2011) http://ec.europa.eu/environment/pubs/pdf/ factsheets/biodiversity_2020/2020\%20Biodiversity\%20Fac tsheet_EN.pdf

Eyre MD, Luff ML, Woodward JC (2003) Beetles (Coleoptera) on brownfieldsites in England: an important conservation resource? J Insect Conserv 7:223-231. https://doi.org/10.1023/ B:JICO.0000021020.66549.1eFahrig

Fetridge ED, Ascher JS, Langellotto GA (2008) The bee fauna of residential gardens in a suburb of new York City (Hymenoptera: Apoidea). Ann Entomol Soc Am 101:1067-1077. https://doi. org/10.1603/0013-8746-101.6.1067

Fischer LK, von der Lippe M, Rillig MC, Kowarik I (2013a) Creating novel urban grasslands by reintroducing native species in wasteland vegetation. Biol Conserv 159:119-126. https://doi. org/10.1016/j.biocon.2012.11.028

Fischer LK, von der Lippe M, Kowarik I (2013b) Urban grassland restoration: which plant traits make desired species successful colonizers? Appl Veg Sci 16:272-285. https://doi.org/10.1111/ j.1654-109X.2012.01216.x

Fischer LK, Eichfeld J, Kowarik I, Buchholz S (2016) Disentangling urban habitat and matrix effects on wild bee species. PeerJ. https ://doi.org/10.7717/peerj.2729

Fortel L, Henry M, Guilbaud L, Al G, Kuhlmann M, Mouret H, Rollin O, Vaissière BE (2014) Decreasing abundance, increasing diversity and changing structure of the wild bee community (Hymenoptera: Anthophila) along an urbanization gradient. PLoS ONE 9(8):e104679. https://doi.org/10.1371/journal.pone.0104679

Gallagher FJ, Pechmann I, Holzapfel C, Grabosky J (2011) Altered vegetative assemblage trajectories within an urban brownfield. Environ Pollut 159:1159-1166. https://doi.org/10.1016/j.envpo 1.2011.02.007

Gandy M (2013) Marginalia: aesthetics, ecology, and urban wastelands. Ann Assoc Am Geogr 103(6):1301-1316. https://doi. org/10.1080/00045608.2013.832105

Gardiner MM, Burkman CE, Prajzner SP (2013) The value of urban vacant land to support arthropod biodiversity and ecosystem services. Environ Entomol 42:1123-1136. https://doi.org/10.1603/ EN12275

Gardiner MM, Prajzner SP, Burkman CE, Albro S, Grewal PS (2014) Vacant land conversion to community gardens: influences on generalist arthropod predators and biocontrol services in urban greenspaces. Urban Ecosyst 17:101-122. https://doi.org/10.1007/ s11252-013-0303-6

Gathmann A, Tscharntke T (2002) Foraging ranges of solitary bees. J Anim Ecol 71:757-764. https://doi.org/10.104 6/j.1365-2656.2002.00641.x

Goddard MA, Dougill AJ, Benton TG (2009) Scaling up from gardens: biodiversity conservation in urban environments. Trends Ecol Evol 25(2):90-98. https://doi.org/10.1016/j.tree.2009.07.016

Godefroid S, Monbaliu D, Koedam N (2007) The role of soil and microclimatic variables in the distribution patterns of urban wasteland flora in Brussels, Belgium. Landsc Urban Plan 80(1-2):45-55

Gotelli NJ, Colwell RK (2001) Quantifying biodiversity: procedures and pitfalls in measurment and comparison of species richness. Ecol Lett 4:379-391

Greenleaf SS, Williams NM, Winfree R, Kremen C (2007) Bee foraging ranges and their relationship to body size. Oecologia 153(3):589-596
Hahs AK, McDonnell MJ, McCarthy M, Vesk P, Corlett R, Norton B, Clemants SE, Duncan RP, Thompson K, Schwartz MW, Williams N (2009) A global synthesis of plant extinction rates in urban areas. Ecol Lett 12:1165-1173. https://doi.org/10.111 1/j.1461-0248.2009.01372.x

Hall DM, Camilo GR, Tonietto RK, Ollerton J, Ahrné K, Arduser M, Ascher JS, Baldock KCR, Fowler R, Frankie G, Goulson D, Gunnarsson B, Hanley ME, Jackson JI, Langellotto G, Lovenstein D, Minor ES, Philpot SM, Potts SG, Sirohi MH, Spevak EM, Stone GN, Threlfall CG (2017) The city as a refuge for insect pollinators. Conserv Biol 31:24-29

Hamblin AL, Youngsteadt E, Steven DF (2018) Wild bee abundance declines with urban warming, regardless of floral density. Urban Ecosyst. https://doi.org/10.1007/s11252-018-0731-4

Heneberg P, Bogusch P, Rehounek J (2013) Sandpits provide critical refuge for bees and wasps (Hymenoptera: Apocrita). J Insect Conserv 17:473-490. https://doi.org/10.1007/s1084 1-012-9529-5

Hinners SJ, Kearns CA, Wessman CA (2012) Roles of scale, matrix, and native habitat in supporting a diverse suburban pollinator assemblage. Ecol Appl 22(7):1923-1935

Holzer KA (2014) Amphibian use of constructed and remnant wetlands in an urban landscape. Urban Ecosyst 17:955-968. https://doi. org/10.1007/s11252-014-0373-0

Horn H (1966) Measurement of 'overlap' in comparative ecological studies. Am Nat 100:419-424

Kasprzak K, Niedbała W (1981) Wskaźniki biocenotyczne stosowane przy porządkowaniu i analizie danych w badaniach ilościowych. In: Górny M, Grum L (eds) Metody stosowane w zoologii gleby. Wyd. Naukowe PWN, Warszawa

Kattwinkel M, Biedermann R, Kleyer M (2011) Temporary conservation for urban biodiversity. Biol Conserv 144:2335-2343. https://doi.org/10.1016/j.biocon.2011.06.012

Kearns CA, Oliveras DM (2009) Environmental factors affecting bee diversity in urban and remote grassland plots in Boulder, Colorado. J Insect Conserv 13:655-665. https://doi.org/10.1007/ s10841-009-9215-4

Knight ME, Martin AP, Bishop S, Osborne JL, Hale RJ, Sanderson RA, Goulson D (2005) An interspecific comparison of foraging range and nest density of four bumblebee (Bombus) species. Mol Ecol 14(6):1811-1820

Kovach WL (2002) Multivariate Statictical Package. Version 3.22. Pentraeth. Wales. UK

Kowalczyk JK, Szczepko K, Kurzac T (2008) Stan poznania pszczół (Hymenoptera, Apoidea, Apiformes) w Łodzi. In: Indykiewicz P, Jerzak L, Barczak T (eds) Fauna miast. Ochronić różnorodność biotyczną w miastach. SAR "Pomorze", Bydgoszcz, pp 246-252

Kowarik I (2011) Novel urban ecosystems, biodiversity, and conserva-tion. Environ Pollut 159:1974-1983. https://doi. org/10.1016/j.envpol.2011.02.022

Kowarik I, Langer A (2005) Natur-Park Südgelände: linking conservation andrecreation in an abandoned railyard in Berlin. In: Kowarik I, Körner S (eds) Wild urban woodlands. Springer, Berlin, pp 287-299

Krauss J, Alfert T, Steffan-Dewenter I (2009) Habitat area but not habitat age determines wild bee richness in limestone quarries. J Appl Ecol 46:194-201. https://doi.org/10.111 $1 / \mathrm{j} .1365-2664.2008 .01582 . x$

Lermann SB, Milam J (2016) Bee fauna and floral abundance within lawn-dominated suburban yards in Springfield, MA. Conserv Biol Biodiv 109(5):713-723. https://doi.org/10.1093/aesa/ saw043

Lermann SB, Contosta AR, Milam J, Bang Ch (2018) To mow or to mow less: lawn mowing frequency affects bee abundance and 
diversity in suburban yards. Biol Conserv 221:160-174. https ://doi.org/10.1016/j.biocon.2018.01.025

Lönnberg L, Jonsell M (2012) Sand pits as habitats for beetles (Coleoptera): does area affect species number and composition? Biodiver Conserv 21(3):853-874. https://doi. org/10.1007/s10531-012-0225-2

Lundholm JT, Richardson PJ (2010) Habitat analogues for reconciliation ecology in urban and industrial environments. J Appl Ecol 47:966-975. https://doi.org/10.1111/j.1365-2664.2010.01857 $\mathrm{x}$

Martins KT, Gonzales A, Lechowicz MJ (2017) Patterns of pollinator turnover and increasing diversity associated with urban habitats. Urban Ecosyst. https://doi.org/10.1007/s11252-017-0688-8

Matteson KC, Ascher JS, Langellotto GA (2008) Bee richness and abundance in New York city urban gardens. Conserv Biol Biodiv 101(1):140-150. https://doi.org/10.1603/00138746(2008)101\%5b140:BRAAIN\%5d2.0.CO;2

Maurer U, Peschel T, Schmitz S (2000) The flora of selected urban land-use types in Berlin and Potsdam with regard to nature conservation in cities. Landsc Urban Plan 46(4):209-215

McDonnell MJ, Hahs AK (2008) The use of gradient analysis studies in advancing our understanding of the ecology of urbanizing landscapes: current status and future directions. Landsc Ecol 23(10):1143-1155. https://doi.org/10.1007/s10980-008-9253-4

McFrederick QS, Le Buhn G (2006) Are urban parks refuges for bumble bees Bombus spp. (Hymenoptera: Apoidea)? Biol Conserv 129:372-382

McIntyre NE, Hostetler ME (2001) Effects of urban land use on pollinator (Hymenoptera: Apoidea) communities in a desert metropolis. Basic Appl Ecol 2:209-218

McKinney ML (2002) Urbanization, biodiversity and conservation. Bioscience 52:883-890. https://doi.org/10.1641/00063568(2002)052\%5b0883:UBAC\%5d2.0.CO;2

McKinney ML (2006) Urbanization as a major cause of biotic homogenization. Biol Conserv 127:247-260. https://doi.org/10.1016/j. biocon.2005.09.005

McKinney ML (2008) Effects of urbanization on species richness: a review of plants and animals. Urban Ecosyst 11:1573-1642. https ://doi.org/10.1007/s11252-007-0045-4

Menke SB, Guenard B, Sexton JO, Weiser MD, Dunn RR, Silverman J (2011) Urban areas may serve as habitat and corridors for dry-adapted, heat tolerant species; an example from ants. Urban Ecosyst 14:135-163. https://doi.org/10.1007/s11252-010-0150-7

Meyer B, Gaebele V, Steffan-Dewenter ID (2007) Patch size and landscape effects on pollinators and seed set of the horseshoe vetch, Hippocrepis comosa, in an agricultural landscape of central Europe. Entomol Gen 30:73-185. https://doi.org/10.1127/entom .gen/30/2007/173

Michener ChD (2007) The bees of the world. The Johns Hopkins University Press, Baltimore

Middle I, Dzidic P, Buckley A, Bennett D, Tye M, Jones R (2014) Integrating community gardens into public parks: an innovative approach for providing ecosystem services in urban areas. Urban For Urban Gree 13(4):638-645. https://doi.org/10.1016/j. ufug.2014.09.001

Muratet A, Machon N, Jiguet F, Moret J, Porcher E (2007) The role of urban structures in the distribution of wasteland flora in the greater Paris area, France. Ecosystems 10(4):661

Niemelä J (1999) Ecology and urban planning. Biodiver Conserv 8:119-131

Normandin É, Vereecken NJ, Buddle ChM, Fournier V (2017) Taxonomic and functional trait diversity of wild bees in different urban settings. PeerJ. https://doi.org/10.7717/peerj.3051

Öckinger E, Dannestam Å, Smith HG (2009) The importance of fragmentation and habitat quality of urban grasslands for butterfly diversity. Landsc Urban Plan 93(1):31-37
Oksanen J, Blanchet FG, Kindt R, Legendre P, O'Hara RB, Simpson GL, Solymos P, Stevens MHH, Wagner H (2011) vegan: Community Ecology Package. R package version 1.17-11. http:// CRAN.R-project.org/package $=$ vegan

Pawlikowski T, Celary W (2003) Klucze do oznaczania owadów Polski. Cz. XXIV Błonkówki-Hymenoptera. Wstęp i podrodzina lepiarkowate-Colletidae. Polskie Tow Entomol, Toruń

Pesenko YA, Banaszak J, Cierniak T (2002) Klucze do oznaczania owadów Polski, Cz. XXIV Błonkówki Hymenoptera. Halictinae. Polskie Towarzystwo Entomologiczne, Torun

Potts SG, Vulliamy B, Roberts S, O'Toole C, Dafni A, Ne'eman G, Willmer P (2005) Role of nesting resources in organising diverse bee communities in a Mediterranean landscape. Ecol Entomol 30:78-85

R Development Core Team (2017) R: A language and environment for statistical computing. R Foundation for Statistical Computing. Vienna, Austria. ISBN: 3-900051-07-0. http://www.R-project.org

Rall EL, Haase D (2011) Creative intervention in a dynamic city: a sustainability assessment of an interim use strategy for brownfields in Leipzig, Germany. Landsc Urban Plan 100:189-201. https:// doi.org/10.1016/j.landurbplan.2010.12.004

Roberts DW (2010) labdsv: Ordination and Multivariate Analysis for Ecology. R package version 1.4-1. http://CRAN.R-project.org/ package $=$ labdsv

Rupprecht CDD, Byrne JA (2014) Informal urban green-space: comparison of quantity and characteristics in Brisbane, Australia and Sapporo, Japan. PLoS ONE. https://doi.org/10.1371/journ al.pone.0099784

Rutkowski L (2004) Klucz do oznaczania roślin Polski niżowej. Wydawnictwo Naukowe PWN, Warszawa, p 814

Saure C (1996) Urban habitats for bees: the example of the city of Berlin. In: Matheson SLBA, OÓToole C, Westrich P, Williams IH (eds) The conservation of bees. Academic Press, New York, pp 47-53

Savard JPL, Clergeau P, Mennechez G (2000) Biodiversity concepts and urban ecosystems. Landsc Urban Plan 48:131-142

Scheuchl E (1995) Illustrierte Bestimmungstabellen der Wildbinen Deutschlands und Osterreichs 1: Anthophoridae. Eigenverlag, Velden

Schmid-Egger C, Scheuchl E (1997) Illustrierte Bestimmungstabellen der Wildbinen Deutschlands und Osterreichs 3: Andrenidae. Eigenverlag, Velden

Shochat E, Lerman SB, Anderies JM, Warren PS, Faeth SH, Nilon $\mathrm{CH}$ (2010) Invasion, competition, and biodiversity loss in urban ecosystems. Bioscience 60(3):199-208. https://doi.org/10.1525/ bio.2010.60.3.6

Small EC, Sadler JP, Telfer MG (2003) Carabid beetle assemblages on urbanderelict sites in Birmingham, UK. J Insect Conserv 6:233-246. https://doi.org/10.1023/A:1024491111572

Sørensen T (1948) A method for establishing groups of equal amplitude in plant sociology based on similarity of species content and its application to analyses of the vegetation on Danish commons. Biol Skrif 5:1-34

Steffan-Dwenter I, Tscharntke T (2000) Resource overlap and possible competition between honey bees and wild bees in central Europe. Oecologia 122:288-296

ter Braak CJ, Šmilauer P (1998) CANOCO Reference Manual and User's Guide to Canoco for Windows: Software for Canonical Community Ordination (version 4). Microcomputer Power (Ithaca, NY, USA)

Threlfall CG, Kendal D (2018) The distinct ecological and social roles that wild spaces play in urban ecosystems. Urban For Urban Gree 29:348-356. https://doi.org/10.1016/j.ufug.2017.05.012

Threlfall CG, Walker K, Williams NS, Hahs AK, Mata L, Stork N, Livesley SJ (2015) The conservation value of urban green space 
habitats for Australian native bee communities. Biol Conserv 187:240-248

Tommasi D, Miro A, Higo HA, Winston ML (2004) Bee diversity and abundance in an urban setting. Can Entomol 136:851-869. https ://doi.org/10.4039/n04-010

Tonietto R, Fant J, Ascher J, Ellis K, Larkin D (2011) A comparison of bee communities of Chicago green roofs, parks and prairies. Landsc Urban Plan 103(1):102-108. https://doi.org/10.1016/j. landurbplan.2011.07.004

Westrich P (1989) The wild bees of Baden-Württemberg. The wild bees of Baden-Württemberg
Wojcik VA, McBride JR (2012) Common factors influence bee foraging in urban and wildland landscapes. Urban Ecosyst 15(3):581-598

Zerbe S, Maurer U, Schmitz S, Sukopp H (2003) Biodiversity in Berlin and its potential for nature conservation. Landsc urban planning 62(3):139-148

Publisher's Note Springer Nature remains neutral with regard to jurisdictional claims in published maps and institutional affiliations. 